\title{
USE OF DETONATION SPUTTERING TO INCREASE THE DURABILITY OF HYDRAULIC HAMMER CRITICAL PARTS
}

\author{
D.B. Hlushkova ${ }^{1}$, I.H. Kyrychenko ${ }^{1}$, V.A. Bahrov ${ }^{1}$, N.Ye. Kalinina ${ }^{2}$, T.V. Nosova ${ }^{2}$ \\ ${ }^{1}$ Kharkiv National Automobile and Highway University, Kharkiv, Ukraine; \\ ${ }^{2}$ Oles Honchar Dnipro National University, Dnipro, Ukraine \\ E-mail: diana@khadi.kharkov.ua
}

\begin{abstract}
Currently, the use of new methods of surface strengthening has become relevant to improve the working tool. These methods include detonation sputtering. The purpose of this work was to scientifically substantiate and experimentally confirm the effectiveness of strengthening critical parts of a hydraulic hammer by detonation sputtering. As a result of the study, the effect of detonation sputtering on the wear resistance and mechanical properties of the hydraulic hammer working tool was established, and structural changes in the material during its operation were analyzed. The results of testing parts strengthened with detonation sputtering show that an increase in wear resistance by 1.8 times is achieved compared to the initial state.
\end{abstract}

PACS: 81.15.Cd

\section{INTRODUCTION}

The development of modern technology sets up increasing demands on the performance characteristics of hydraulic hammer parts. In the complex of problems of improving reliability and durability thereof, a special place is occupied by the issue of wear resistance. Insufficient wear resistance limits the performance of hydraulic hammers and their service life, and increases repair costs.

In order to improve the performance characteristics of the working tools of hydraulic hammers, new methods of surface strengthening, including detonation coating methods, are widely used.

\section{REVIEW OF RECENT PAPERS}

Currently, two types of hydraulic hammers are produced: diaphragm and piston type. Their schematic diagram is almost identical, but there are big differences in how the work cycle is organized and how the impact energy is generated.

Working cycle of the diaphragm type hydraulic hammer (Fig. 1) is carried out in several steps. When the hydraulic hammer is switched on, the working fluid (nitrogen) enters the pressure line hydraulic accumulator and the gas chamber through a check valve [1].

At the outlet of the drain line, there is a slide valve that blocks it until the pressure inside the hydraulic accumulator reaches the calculated value. After reaching the required pressure, the slide valve opens the drain line, and the striker moves up.

After moving the striker, the control valve opens, and the slide valve changes position to the working stroke. Due to the fact that the size of the working stroke chamber exceeds the size of the idling chamber, the striker slows down and begins to move towards the working tool.

Before the impact, the control channel is combined with the drain line, the slide valve changes position backwards, and the working cycle is repeated.

For the piston type hydraulic hammer (Fig. 2) there is no check valve at the inlet, pressure slide valve at the outlet, hydraulic accumulator [2].
Both types of piston hydraulic hammers are characterized by the formation of shock energy in the piston pneumatic accumulator. During idling of the striker, part of it enters the pneumatic chamber, additional nitrogen compression occurs, collecting about $70 \%$ of the impact energy. The remaining $30 \%$ of the energy is generated by the hydraulic line. The areas of the working and idling chambers are designed so that high pressure peaks do not occur in the hydraulic system. The role of a hydraulic accumulator is performed by pipelines and high-pressure hoses that connect the hydraulic hammer and pump.

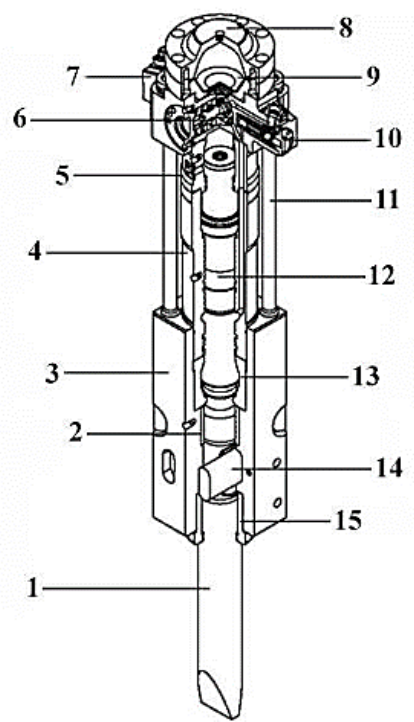

Fig. 1. Membrane type hydraulic hammer structure: 1 -working tool; 2 - upper sleeve;

3 -front head; 4-cylinder; 5 - seal body; 6-sleeve;

7 -valve body; 8 - battery; 9 - diaphragm;

10 -working valve; 11 - tie bolt; 12 - piston;

13 - thrust ring; 14 - working tool pin;

15 - working tool sleeve [1]

During the operation of hydraulic hammers, its working tool is worn out.

Working tool is the industry name for a variable part of the hydraulic hammer that directly interacts with the 
materials that destroys and transmits power and impact loads to the object of destruction.

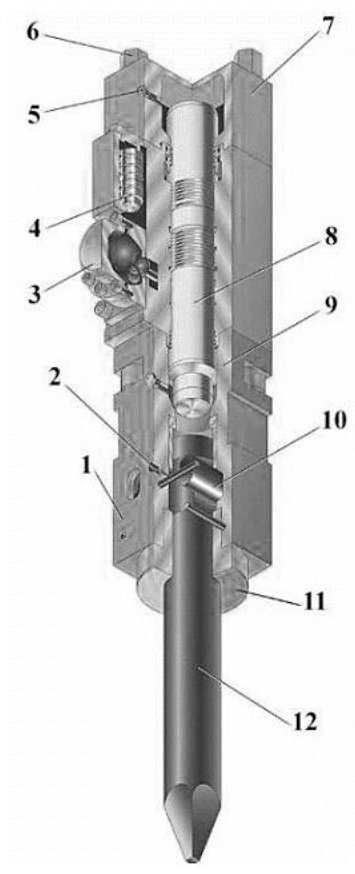

Fig. 2. Hydraulic piston hammer structure:

1 - lower body; 2 -oil pan; 3 - hydraulic accumulator;

4 - hydraulic distributor; 5 -nitrogen filling valve;

6 - tie bolt (stud); 7 - cylinder cover; 8 - piston;

9 -working cylinder; 10 - pin; 11 -lower sleeve;

12 - working tool (peak) [2]

The main principle of typing the hydraulic hammer working tool is the type of contact of the tool with the material that is being destroyed, according to which it can be divided [3] into a tool with a constant contact area and an area that changes in the process of interaction with the material, the last can be divided into the groups: with the initial contact along the line; with the initial contact at the point; with the initial contact along the site.

The parameters of a tool with a constant contact area are determined by its shape and dimensions - the radius, length, width, dimensions of the semi-axes of the ellipse; ones with an area that changes during interaction with the material - the length and angle of sharpening, radii of the sphere or torus, the shape and size of the initial contact site. The common name of all types of hydraulic hammer working tools is "peak".

The hammer working tool is cyclically affected by compressive forces, both from the tail section, after being hit by the hydraulic hammer striker, and from the tool tip by the reactive force of the treated medium. The compressive forces that cause elastic deformations, differentially distributed along the length of the tool, are replaced by inertial tensile forces. They alternate with the frequency of hydraulic hammer operation, creating wave processes of stretching/compression, resulting in material fatigue. If the hydraulic hammer works for a long time "at one point", they can cause a resonance phenomenon that contributes to the destruction of the tool.

In the process of interaction with the treated medium, intensive wear of the working tool occurs, accompanied by strain hardening of its surface, release of heat, which can lead to local tempering of the material from which it is made, with loss of surface hardness. As a result, there is an increase in the degree of blunting of the tool. The intensity of the wear process depends on the strength and abrasiveness of the medium being destroyed, as well as the wear resistance of the tool, which, as is commonly believed [4], is determined primarily by the hardness of the working tool used.

Currently, coating methods are widely used in mechanical engineering, which have significant advantages: limited thermal effect, reduction of deformations, minimal fusion penetration depth ensures slight mixing of the base metal with the coating metal and allows you to obtain physical and mechanical properties of coatings close to the properties of the surfacing material. In addition, it is possible to apply coatings of various compositions and with specified physical and mechanical properties to the worn surface, saving material and energy resources by obtaining coatings with minimal stock left for machining or its complete exclusion. The study of the experience of using high-energy power sources, as well as new compositions of coatings for working surfaces, suggests the feasibility of using them to increase the service life of the hydraulic hammer critical parts.

Methods for the surface reconditioning and strengthening of parts are shown in Fig. 3 [5].

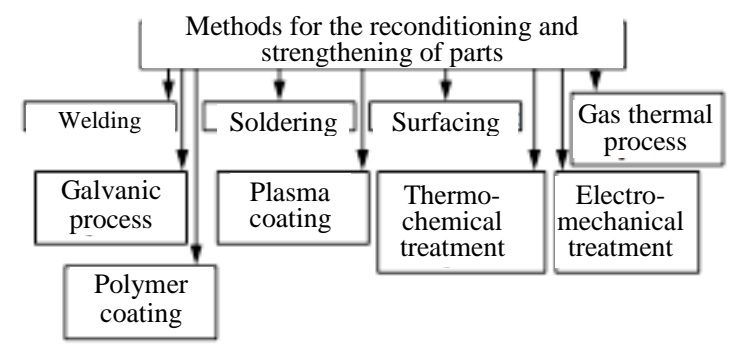

Fig. 3. Methods for the surface reconditioning and strengthening of parts [5]

One of the most promising methods is detonation sputtering. Detonation sputtering is a pilot technology for improving the durability of critical machine parts [4].

\section{PURPOSE AND OBJECTIVES}

The purpose of this work is to scientifically substantiate and experimentally confirm the effectiveness of strengthening critical parts of a hydraulic hammer by detonation sputtering.

Objectives: based on experimental studies, to establish the effect of detonation sputtering of coatings of the system comprising BK-25 (80\%) and the ПT-HA-01 binding material (Ni 91\%, Al 9\%) on the wear resistance of the hydraulic hammer working tool.

\section{MATERIALS AND METHODS}

Detonation sputtering of BK25 hard alloy powder (80\%) and the ПТ-HA-01 binding material (Ni 91\%, $\mathrm{Al} \mathrm{9 \% )}$ was performed on the cleaned surface without pretreatment [6]. BK-25 powder is a tungsten-cobalt (WC-Co) carbide containing up to $25 \%$ cobalt, and is used for working in conditions of fretting corrosion, 
abrasive wear at normal and elevated (up to $650{ }^{\circ} \mathrm{C}$ ) temperatures. A powder with a grain size of $20 . .100 \mathrm{~mm}$ was used; the powder was melted in an oxygen-acetylene flame and transferred to the surface of the part by a gas stream. Thickness of the sputtered layer is $0.1 \mathrm{~mm}$. The surface roughness of the parts before sputtering was Ra 0.35-2.5. As a result of sputtering, the roughness of the working surfaces of parts increased to $\mathrm{Ra} 4.8-5.4$.

The ratio of oxygen content to acetylene content was $1 / 2$; powder loading depth was $300 \mathrm{~mm}$, spray distance was $150 \mathrm{~mm}$, powder weight was $200 \mathrm{~g}$, barrel length was $1.6 \mathrm{~m}$, barrel diameter was $16 \mathrm{~mm}$.

Detonation coatings are a type of gas thermal coatings, and increasingly used in various industries due to their higher characteristics. Due to the highest characteristics (adhesion strength to the substrate up to $250 \ldots 280 \mathrm{MPa}$ ), detonation sputtering can be preferred for strengthening and reconditioning critical and loaded parts and assemblies.

It is established that coatings based on tungsten carbide from powders obtained by spheroidization have the highest adhesion strength to the substrate and high hardness. This is due to the fact that the dissolution of $\mathrm{WC}$ in $\mathrm{Co}(\mathrm{Ni})$ partially occurs already when the powder is obtained.

During sputtering, this process continues, as a result of which the solid solution has a maximum degree of saturation [7].

In addition to the dissolution of tungsten carbide in cobalt, when sputtered under the influence of an oxidizing medium, the process of decomposition of monocarbide occurs, which has a negative impact on the quality of the sputtered coating. In addition, brittle double carbides $\mathrm{Co}_{3} \mathrm{~W}_{3} \mathrm{C}$ are formed, which degrade the properties of the sputtered layer. In powders obtained by spheroidization, the carbide component is better protected. The modes of the sputtering process also significantly affect the structural-phase composition of coatings and, consequently, their properties. The coating structure is most strongly influenced by $[8,9]$ :

- composition of the working gas mixture;

- place of supplying the powder into the trunk;

- the degree of filling of the trunk with the working mixture.

The adhesion strength to the substrate of combined coatings with BK-25 sublayer reaches $200 \ldots 250 \mathrm{MPa}$, Rockwell Hardness - up to 70.

A distinctive feature of detonation sputtering is the cyclical nature of powder delivery to the surface of the workpiece at a speed exceeding the speed of sound. The cyclic sputtering process is obtained using detonation units, the schematic diagram of which is shown in Fig. 4 [7].

The unit includes detonation gun, powder and combustible gas dispensers, and ignition system. The protective chamber is formed by a part (4) being sputtered and two covers $(5,6)$, one of which is mounted on the trunk (1) of the gun and is equipped with an elastic element. The gun is mounted on horizontal movement mechanism (7); it consists of a trunk, combustion chamber (2) and accelerating part (3).

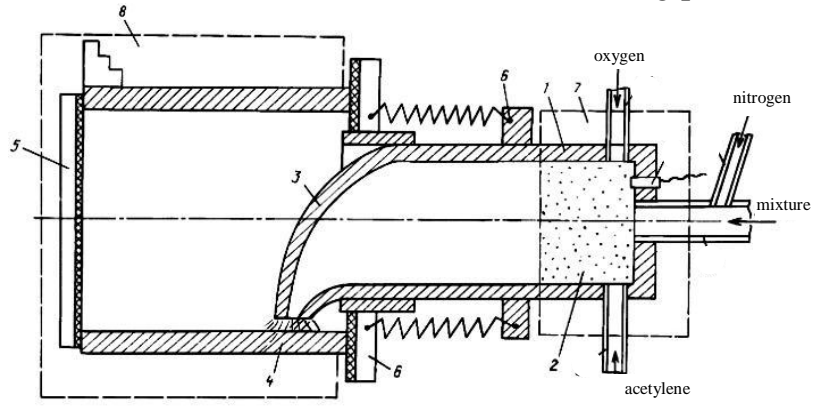

Fig. 4. Diagram of detonation units [7]

The accelerating part is formed by bending the end of the trunk along the radius to a right angle with a conical narrowing at the end with a ratio of diameters from $1 / 3$ to $1 / 4$. The trunk and accelerating part of the detonation gun is located inside the part being sputtered. The part is rotated by the mechanism (8). It provides the possibility of detonation sputtering of the internal surfaces of parts to increase their wear resistance.

The principle of operation of the unit is as follows. From Block 1, the gas mixture is fed to trunk 5. At the same time, fine powder is blown from the powder feeder through the metering device (block 4) in specified portions with nitrogen or air gas into the gas mixture immediately before its ignition, and then the gas mixture is ignited with the igniter 2. As a result of ignition and movement of the ignitable mixture through the channel, its explosion occurs with the release of a significant amount of heat and the formation of a detonation wave, which accelerates and transfers through the barrel to the surface of the part 6 by sputtering the particles 7 at the speed determined by the trunk geometry and gas composition.

\section{STATEMENT OF BASIC MATERIALS}

The process of forming coatings by detonation sputtering is complex and insufficiently studied. In many ways, it is similar to the process of plasma sputtering $[10,11]$. The similarity is in the fact that the adhesion of particles to the substrate and to each other can occur in the molten and solid states. The adhesion strength is mainly provided by sputtering with molten and melted particles, which spread and crystallize on the substrate surface due to chemical interaction.

At the same time, the detonation sputtering, in contrast to continuous plasma sputtering, is cyclic, powder particles are provided with higher speeds, which determine the features of the coating formation mechanism.

During detonation sputtering, the particle speed, in contrast to plasma sputtering $(100 \ldots 200 \mathrm{~m} / \mathrm{s})$ reaches $400 \ldots 1000 \mathrm{~m} / \mathrm{s}$. Therefore, in addition to thermal activation, plastic deformation in the zone of contact between particles and the substrate has a significant effect on the mechanism and kinetics of formation of sputtered layers. However, the main contribution to the formation of coatings during sputtering is made by thermal activation.

The experience of using various sputtering methods, including detonation, proves that in order to obtain a 
satisfactory adhesion of powder particles to the substrate, it is necessary that a significant part of them is transported to the substrate in molten or melted state. Experimental studies on the process of forming coatings by detonation sputtering presented in $[11,12]$ show that the state of particles in a two-phase flow is inhomogeneous.

At the beginning and in the middle of the flow, they are in molten or melted state, and the temperature in contact with the substrate reaches their melting point. At the same time, due to the heat released when particles with a speed of $\sim 400 \mathrm{~m} / \mathrm{s}$ hit the substrate, the temperature in the contact zone increases by about $100{ }^{\circ} \mathrm{C}$.

When sputtered with powder materials with a melting point exceeding the melting point of the base metal, the latter is melted. When applying coatings with powdered hard alloys of the BK type on corrosionresistant steels, which are melted and mixed with molten particles of the powder that is sputtered, thereby increasing the adhesion strength.

Preliminary shot blasting of the sputtered surface contributes to an increase in adhesion, as with other methods of gas thermal sputtering $[12,13]$. In this case, it is possible to obtain strong bonds between the sputtered material and the substrate with hardness higher than $60 \mathrm{HRC}$.

When the first layer is sputtered, pores may appear. When the second layer is sputtered, the powder particles deform and compact the first layer, which crystallizes, and helps to eliminate or reduce porosity. This phenomenon is characteristic of detonation sputtering, and the authors of [12] called it "the effect of hot impact pressing".

Larger particles from the end (tail) of a less concentrated stream have lower speed and are most often deposited on the substrate surface in an undiluted form. When forming a coating, such particles play a twofold role: useful - remove defective areas of the previously applied coating, increasing its density, physical and mechanical properties; adverse - with a significant increase in the kinetic energy of large particles, cracks and even complete peeling may appear in the coating. These phenomena can be adjusted by changing the rate of fire mode of the unit and the granulation of the sputtered powder.

From the point of view of the materials and equipment used, the detonation sputtering process is quite simple. The main factors determining the nature of detonation sputtering are the gas mixture, powders, and the trunk of the unit $[13,14]$.

However, the use of these factors in the technological process of sputtering is associated with changing and controlling a number of parameters of each of them. For a gas mixture, this is the composition of the gas mixture; dose of the gas mixture per shot; composition of the gas mixture in the trunk between shots. For powder this is chemical composition of the powder; granulation of the sputtered powder; location of the powder in the barrel at the time of ignition of the mixture; distribution of particles by size. The trunk is characterized by geometric parameters: diameter and length.
In turn, these parameters give rise to others that characterize the final state of the process: concentration, temperature and speed of particles; chemical composition of the medium; surface temperature of the substrate.

Thus, the technological process of detonation sputtering is complex, and the quality of coating formation depends on the totality of numerous parameters, their maintenance within optimal limits.

Studies of the wear resistance of parts strengthened by detonation sputtering were carried out by bench tests. The tests were carried out for 1800 cycles.

The type of damage to parts strengthened with detonation sputtering is shown in Figs. 5, 6.

The location and nature of damage to the surfaces of parts of the same type and observed on previously studied sets of the device. On the body and sleeve, such characteristic signs of the surface volume degradation of the part material are noted as wear, strain hardening, plastic deformation with the formation of radial furrows, surface oxidation.

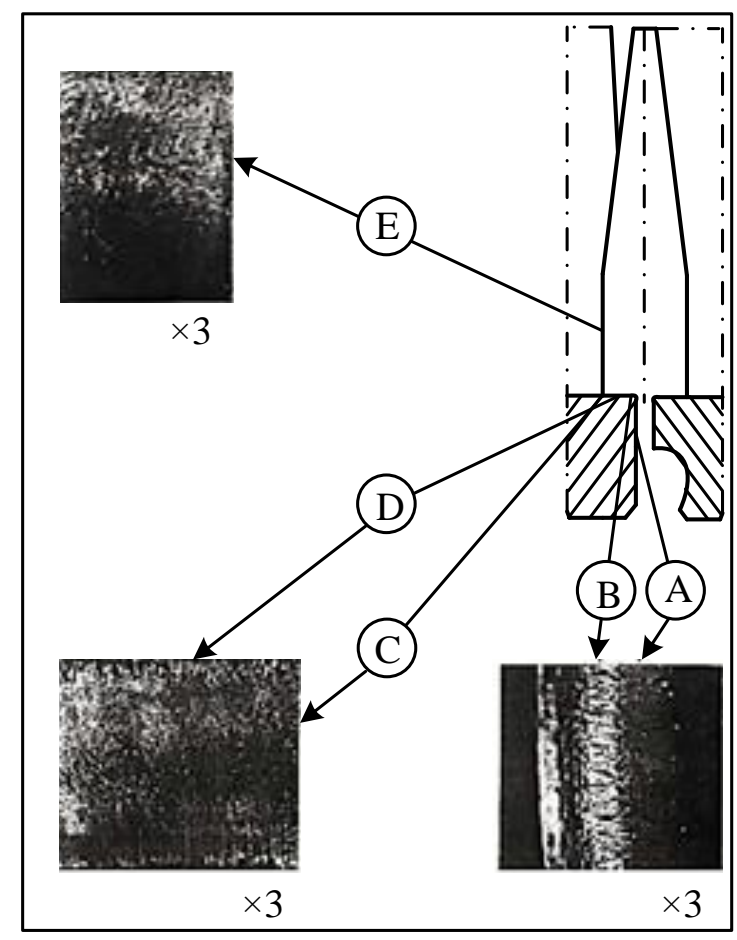

Fig. 5. Damage to peaks and sleeves strengthened by detonation sputtering

In Zone "A", wear and strain hardening are observed on the body, and shear lines are characteristic on the sleeve. In Zone "B", a weakly expressed fold-shaped relief is noted on the body, on the sleeve the relief of furrows is smoothed to the base, so that a picture of undulating crumple zones is observed. Peeling of the surface layers of metal in Zone " $C$ " differs on the sleeve, on the body - the surface is smooth. In Zone " $D$ " there are traces of surface treatment.

The wear pattern of the striker and peak is typical. In the presence of a central spot and furrows in the peripheral part of Zone "N", A folded relief of furrows in Zone "M", wear and plastic deformation with the formation of a rough, peeling surface in Zone " $F$ " and wear with a strain hardening in Zone " $E$ ", there is a 
smaller "roughness" of the relief and a larger smoothed one for the striker and peak. On the striker, the degree of damage is less.

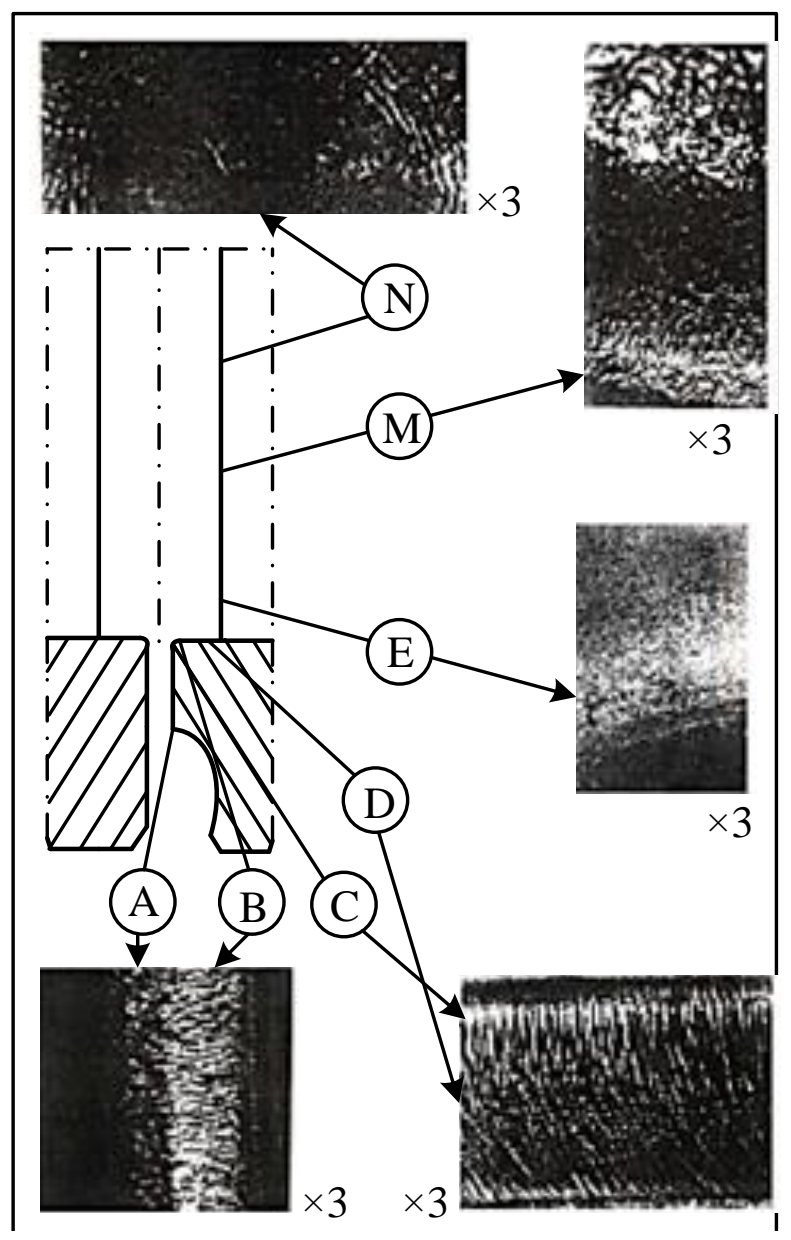

Fig. 6. Damage to the body and striker strengthened with detonation coating

The body and striker are characterized by the presence of darker oxidizing colors on the surface.

During the test, cracks formed on all the examined parts of the device. On the sleeve, cracks up to $0.05 \mathrm{~mm}$ deep are isolated and are observed only in Zone " $\mathrm{C}$ " (Fig. 7). On the body, cracks are visible in Zones "A", "B" and "C", with depth of $0.25 \mathrm{~mm}, 0.4 \mathrm{~mm}$ and $0.1 \mathrm{~mm}$, respectively (Fig. 8).

There are no cracks in Zone "D". Cracks are also not found on the striker and peak in Zone "N". In Zones " $\mathrm{M}$ " of the striker and peak, there are cracks with depth of $0.3 \ldots 0.4 \mathrm{~mm}$. Cracks with a depth of $0.1 \mathrm{~mm}$ are located in Zone " $F$ " of the peak and $0.15 \mathrm{~mm}$ - of the striker. Cracks were found both in and out of the zones of structural changes.

In the working zones of all the studied parts of the device, almost complete wear of the detonation coating occurred during the test, only in Zone " $\mathrm{M}$ " of the body and sleeve, coating residues up to $20 \mu \mathrm{m}$ thick are observed. The same single sites are located on the striker in Zone "F".

Structural changes in the base metal were detected in the damage zones of all parts. On the body and sleeve, structural changes are observed in Zones " $\mathrm{A}$ " and " $\mathrm{B}$ " to depth of about $0.2 \mathrm{~mm}$ on the body and $0.15 \mathrm{~mm}$ on the sleeve.
The hardness of the material in these zones is HV 414-540 on the body and HV 414-645 on the sleeve. In zones " $C$ " of the body and sleeve, the depth of structural changes does not exceed $0.05 \mathrm{~mm}$ (HV 460-480).

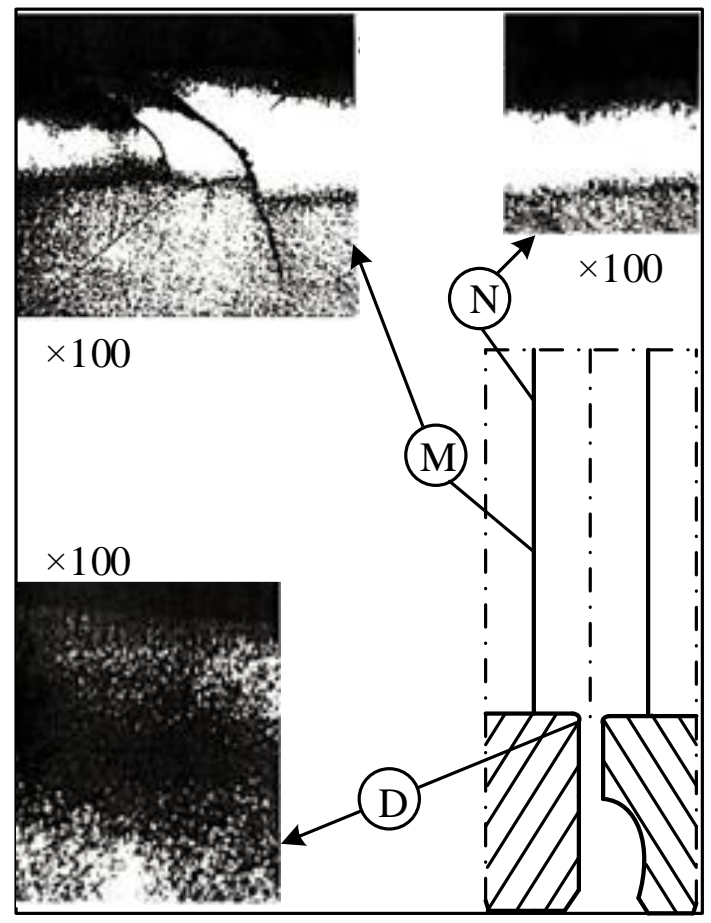

Fig. 7. Structural changes in the material of the body and striker strengthened by detonation sputtering

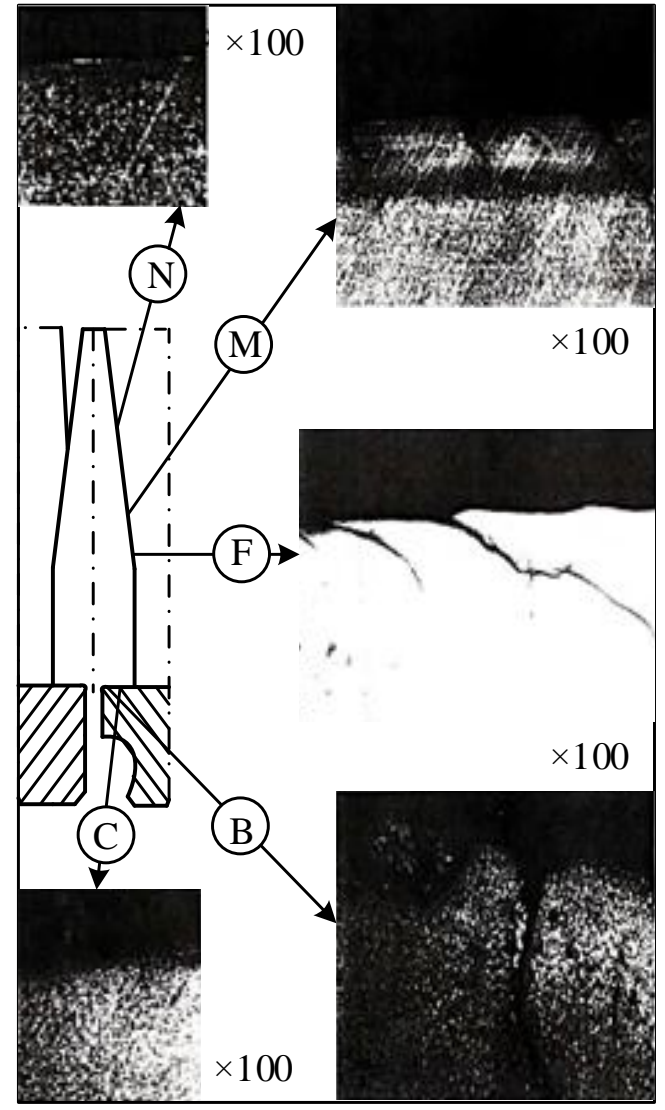

Fig. 8. Structural changes in the material of peak and sleeve strengthened by detonation sputtering 
On the striker and peak, structural changes in the metal are observed in Zone "M" to depth of $0.25 \ldots 0.3 \mathrm{~mm}$ and in Zone "F" to depth of $0.1 \ldots 0.15 \mathrm{~mm}$ (for both) at hardness of HV 340-475 (in some places at the peak - HV 560-675). In Zones "E" on the striker and peak and in Zone " $\mathrm{N}$ " of the striker, there are no structural changes. On the peak in this zone, the depth of structural changes is $0.15 \mathrm{~mm}$ (HV 340560).

\section{CONCLUSIONS}

1. The composition of the detonation coating based on tungsten carbide was chosen to strengthen the surface of the studied parts by detonation sputtering.

2. Detonation sputtering modes are proposed.

3. The conditions for carrying out strengthening treatment are determined.

4. The nature of part damage after detonation sputtering has been established.

5. The results of testing parts strengthened with detonation sputtering show that an increase in wear resistance by 1.8 times is achieved compared to the initial state.

\section{REFERENCES}

1. Structure of hydraulic hammer // Hydroimpuls Group [website]. - Access mode:

http://www.gidroimpulse.ru/gidromolot/construction.ht $\mathrm{ml}$.

2. Review of hydraulic hammer modifications [Digital resource] // Экскаватор PУ. Access mode: https://exkavator.ru/articles/gidromolot/9904obzor_mod ifikacii_gidromolotov.html

3. V.B. Sokolinskii. Shock crushing machines. M.: "Mashinostroenie", 1982, 185 p.

4. V.I. Bolobov, A.P. Batalov, Thanh Bin Le. Wearing behavior of striker during single impacts on mountain rock // Innovations and prospects for the development of mining engineering and electrical engineering: IPDME-2018: Publications of international scientific and practical conference: $\mathrm{SPbU}$, 2018, p. 92.
5. V.V. Eltsov. Reconditioning and strengthening of machine parts: electronic tutorial. Tolyatti: "TltSU Publishing House", 2015. - O-ROM Access mode: https://dspace.tltsu.ru/bitstream/123456789/49/1/Eltsov \%201-81-13\%20-\%20eui\%20-\%20Z.pdf

6. V.I. Chernoivanov, V.P. Lialiakin. Organization and technology of machine part reconditioning. M.: "GOSNITI", 2003, 488 p.

7. V.V. Bykov, I.G. Golubev, V.V. Kamenskii, V.V. Klevakin. Designing technological processes for part reconditioning of transport and technological machines / 2nd ed., rework. and add. M.: "MGUL", 2004, 64 p.

8. A.N. Batishchev, I.G. Golubev, V.P. Lialiakin. Reconditioning of agricultural machinery parts. M.: "Informagrotech", 1995, 295 p.

9. F.I. Pantileenko, S.N. Liubetskii. Materials, technologies and equipment for reconditioning and strengthening machine parts. Part 1. Surfacing and sputtering. Novopolotsk, 1994, $116 \mathrm{p}$.

10. V.K. Panin, P.V. Makarov, S.V. Panin. Influence of thin strength coating of the deformation and fracture mechanisms // Int. Conf. "Math. Metli. Phys., Meeh. and Mesomech. Fract.”. Tomsk, 1996, p. 123.

11. D.B. Hlushkova, O.D. Hrinchenko, L.L. Kostina, A.P. Cholodov. The Choice of Material Strengthening of Leading Edges of Working Blades of Turbines // Problems of Atomic Science and Technology. 2018, N 1(113), p. 181-188.

12. K.V. Frolov. Methods of improving machines and modern problems of machine science. M.: "Mashinostroenie", 1984, 224 p.

13. L.I. Gladkikh, S.V. Malykhyn, D.B. Glushkova, S.S. D yachenko, G.P. Kovtun. Residual Stresses and Structure of Titanium and Chromium Nitride Coatings Obtained by a Method of an Ion-Plasma-Enhanced Deposition // Metallofizika i Noveishie Tekhnoloii. 2003, v. 25(6), p. 763-776 (in Russian).

14. D. Leontiev, O.I. Voronkov, V. Korohodskyi, D. Hlushkova, I. Nikitchenko, E. Teslenko, O. Lykhodii. Mathematical Modelling of Operating Processes in the Pneumatic Engine of the Car: SAE Technical Paper 2020-01-2222, 2020. ISSN: 0148-7191; doi:10.4271/2020-01-2222.

\title{
ПРИМЕНЕНИЕ ДЕТОНАЦИОННОГО НАПЫЛЕНИЯ ДЛЯ ПОВЫШЕНИЯ ДОЛГОВЕЧНОСТИ ОТВЕТСТВЕННЫХ ДЕТАЛЕЙ ГИДРОМОЛОТА
}

\author{
Д.Б. Глушкова, И.Г. Кириченко, В.А. Багров, Н.Е. Калинина, Т.В. Носова
}

В настоящее время для повышения долговечности рабочего инструмента стало актуальным применение новых методов поверхностного упрочнения. К таким методам относится детонационное напыление. Цель данной работы - научно обосновать и экспериментально подтвердить эффективность укрепления ответственных деталей гидромолота методом детонационного напыления. В результате проведенного исследования установлено влияние детонационного напыления на износостойкость и механические свойства рабочего инструмента гидромолота, проведен анализ структурных изменений в материале в процессе его эксплуатации. Результаты испытания деталей, упрочненных детонационным напылением, показывают, что достигается повышение износостойкости в 1,8 раза по сравнению с исходным вариантом. 


\title{
ЗАСТОСУВАННЯ ДЕТОНАЦІЙНОГО НАПИЛЕННЯ ДЛЯ ПІДВИЩЕННЯ ДОВГОВІЧНОСТІ ВІДПОВІДАЛЬНИХ ДЕТАЛЕЙ ГІДРОМОЛОТА
}

\author{
Д.Б. Глушкова, І.Г. Кириченко, В.А. Багров, Н.С. Калініна, Т.В. Носова
}

На даний час для підвищення довговічності робочого інструмента стало актуальним застосування нових методів поверхневого зміцнення. До таких методів відноситься детонаційне напилення. Мета даної роботи науково обгрунтувати і експериментально підтвердити ефективність зміцнення відповідальних деталей гідромолота методом детонаційного напилення. В результаті проведеного дослідження встановлено вплив детонаційного напилення на зносостійкість і механічні властивості робочого інструмента гідромолота, проведено аналіз структурних змін у матеріалі у процесі його експлуатації. Результати випробування деталей, зміцнених детонаційним напиленням, показують, що досягається підвищення зносостійкості в 1,8 рази у порівнянні з вихідним варіантом. 